\title{
Evaluation of Field Pea (Pisum sativum L.) Genotypes for Yield and Yield Attributing Traits at High Land of Arsi, South East Ethiopia
}

\author{
Kedir Yimam*, Aliyi Robsa, Gizachew Yilma, Temesgen Abo \\ Kulumsa Agricultural Research Center, Asella, Ethiopia \\ Email address: \\ Kediryimam95@gmail.com (K. Yimam) \\ ${ }^{*}$ Corresponding author \\ To cite this article: \\ Kedir Yimam, Aliyi Robsa, Gizachew Yilma, Temesgen Abo. Evaluation of Field Pea (Pisum sativum L.) Genotypes for Yield and Yield \\ Attributing Traits at High Land of Arsi, South East Ethiopia. Science Journal of Applied Mathematics and Statistics. \\ Vol. 8, No. 6, 2020, pp. 73-80. doi: 10.11648/j.sjams.20200806.11
}

Received: June 26, 2020; Accepted: September 16, 2020; Published: November 23, 2020

\begin{abstract}
The production and productivity of field pea in Ethiopia is constrained by low-yielding potential of land race, susceptibility to diseases like powdery mildew and Ascochyta blight/spot as well as a biotic stresses like frost and soil acidity. The field experiment was conducted in 2018/19 main cropping season at two locations using simple lattice design to evaluate the genetic variability and performance of forty nine field pea genotypes for yield ad yield attributing traits. The combined/pooled / analysis of variance revealed highly significant $(P \leq 0.01)$ to significant $(P \leq 0.05)$ differences among genotypes observed for all traits under study except for number of seeds pod ${ }^{-1}$. The seed yield ranged from 1955 to $5997 \mathrm{~kg} \mathrm{ha}^{-1}$ with a mean of $3803 \mathrm{~kg}$ across the two locations. Two genotypes PDFPT-BEK and P-313-053 were relatively high yielder over the two locations. The genotypic (GCV) and phenotypic (PCV) coefficient of variation (GCV) ranged from (1.07\%) to $(22.40 \%)$ and $(1.22 \%)$ to $(28.18 \%$ for days to maturity and grain yield, respectively for combined analyses. The PCV values were relatively greater than GCV in magnitude for all traits, of which significantly higher PCV than GCV values observed for number of pods per plant, Stand count, powdery mildew and ascocayta blight, but insignificant differences between PCV and GCV values observed for days to flowering, days to maturity, plant height, 1000 seed weight, and grain yield. Broad sense heritability ranged from $23.66 \%$ to $90.73 \%$. The genetic advance as percentage of mean (GAM) varied from $1.92 \%$ to $36.73 \%$. Higher heritability (H2) coupled with high GAM observed for grain yield per ha and Higher heritability (H2) coupled with Moderate or relatively high value of GAM in plant height and seed size. Therefore, improvement of these traits could be done through selection of genotypes based on the phenotypic performance.
\end{abstract}

Keywords: Broad Sense Heritability, Genetic Advance, Genotypic Coefficient of Variation, Phenotypic Coefficient of Variation

\section{Introduction}

In Ethiopia, among pulse crops, field pea (Pisum sativum L.) stands fourth next to faba bean, haricot bean and chickpea in total production and areas coverage [6].

It is grown on 220,508.39 hectares of land with total production of $368,519.065$ tones and productivity of $1.671 \mathrm{t} /$ ha; which accounts $13.79 \%$ from pulses total area coverage and $12.37 \%$ from total production in Ethiopia [6].

Even though wild and primitive forms of field pea species are known to exist; $P$. sativum is more dominant in the production system at the high land of the country [20].

Ethiopia, Western and Central Asia and the Mediterranean region are proposed as possible centers of origin for field pea because of the high pea genetic diversity sampled in these regions [18].

The crop is widely cultivated in potential mid and high altitude areas of the country characterized with elevations of 1800-3000 meters above sea level and receiving average annual rainfall of $700-1100 \mathrm{~mm}$.

Field pea is grown by small-scale farmers on marginal lands with minimum management practices as compared to 
cereals. It has a great economic merit in the livelihood of the farming communities of Ethiopia [30]. It serves as a source of food and feed with valuable and cheap sources of protein as a complement to cereals for the majority of the poor population mainly for those who cannot afford to use proteins from animal source. It is also a good source of cash to the farmers. Due to its pertinent atmospheric nitrogen fixing capacity (up to $60 \mathrm{~kg} \mathrm{ha}^{-1}$ year $^{-1}$ ); field pea is suitable rotational crop in areas where cereal mono cropping is abundant like Arsi and Bale of South Eastern Ethiopia.

Despite its huge importance in the country, the average production and productivity of field pea is very low as compared to a number of cereals and many other countries of the world [11]. It could be due to the inherent low-yielding potential of land race, diseases like powdery mildew (Erysiphepolygoni) and Ascochyta blight/spot (Mycosphaerellapinodes) as well as abiotic stresses like frost are the major constraints, causing substantial yield loss and instability in yield [24, 31].

The aim of field pea breeding programs across the world is to develop new varieties that meet the requirements of growers and consumers. Thus, the targeted traits for improvement in field pea depend on the level of productivity achieved and consumers' and industry requirements in a country. In order to develop cultivars with traits that overcome the constraints peculiar to specific environments, there must be sufficient genetic variation to allow selection for desired traits [27].

The assessment of existing genetic variability in a given gene pool is essential for formulating effective breeding strategies as the existing variability can be used to enhance the yield level of the cultivars. Selection of potential genotypes from the existing germplasm, utilizing them in the hybridization programs and isolation of the superior segregates in the segregating population are the usual breeding strategy in highly self-pollinated crops like field pea.

The existence of high genetic diversity among Ethiopian field pea landraces accessions collected from various geographical regions of Ethiopia were reported [12].

Even if there is high genetic diversity in field pea, the crop yield is small as compared with the productivity of the crop in the world [11] due to different biotic and abiotic stress in the country.

In other ways, there is also an increasing demand of producers for improved field pea varieties which are resistant/tolerant to biotic, abiotic stress and adapted to wide agro-ecology and this must be met by plant breeding efforts. Therefore, to satisfy the demand of producer, there is a need of continuous evaluation of genotypes for further hybridization, new variety development and to replace obsolete variety.

So that; information on the extent and pattern of genetic variability present in a population is paramount to increase field pea production by further improvement of the crop in the country in general and particularly in study area. Therefore, the objective of this study was to evaluate the genetic variability and performance of some field pea genotypes for yield and yield attributing traits.

\section{Materials and Methods}

\subsection{Experimental Sites}

Field experiments were carried out during the main cropping season (June to November 2018/19) at Bekoji and Kofele of South Eastern high land of Ethiopia.

Table 1. Description of the test environments.

\begin{tabular}{lll}
\hline Locations & Bekoji & Kofele \\
\hline Latitude & $\left(07^{0} 31^{\prime} 22^{\prime \prime} \mathrm{N}\right)$ & $\left(07^{0} 04^{\prime} 27^{\prime \prime} \mathrm{N}\right)$ \\
Longitude & $39^{0} 14^{\prime} 46^{\prime \prime} \mathrm{E}$ & $38^{0} 46^{\prime} 45^{\prime \prime} \mathrm{E}$ \\
Altitude (m.a.s.l.) & 2780 & 2660 \\
Total annual rainfall $(\mathrm{mm})$ & 1010 & 1211 \\
Minimum temperature $\left({ }^{\circ} \mathrm{C}\right)$ & 7.9 & 7.1 \\
Maximum temperature $\left({ }^{\circ} \mathrm{C}\right)$ & 16.6 & 18 \\
Agro-ecologies & $\mathrm{CHMH}$ & $\mathrm{CHMH}$ \\
\hline
\end{tabular}

CHMH: Cool Humid Mid Highland

Source (Tamene, 2017)

\subsection{Experimental Materials}

Forty-nine field pea materials including, 21 introduced from Australia; 19 single plants selected from bulked gene pool materials and 9 released varieties were evaluated.

Table 2. List of field pea Genotypes used in the Study.

\begin{tabular}{llll}
\hline No & Genotype & Source & Origin \\
\hline 1 & GPHA-05 & HARC & SPS \\
2 & GPHA-013 & HARC & SPS \\
3 & GPHA-03 & HARC & SPS \\
4 & GPHA-019 & HARC & SPS \\
5 & GPHA-02 & HARC & SPS \\
6 & GPHA-010 & HARC & SPS \\
7 & GPHA-07 & HARC & SPS \\
8 & GPHA-08 & HARC & SPS \\
9 & GPHA-06 & HARC & SPS \\
10 & GPHA-012 & HARC & SPS \\
11 & GPHA-04 & HARC & SPS \\
12 & GPHA-016 & HARC & SPS \\
13 & GPHA-09 & HARC & SPS \\
14 & GPHA-01 & HARC & SPS \\
15 & GPHA-018 & HARC & SPS \\
16 & GPHA-017 & HARC & SPS \\
17 & GPHA-014 & HARC & SPS \\
18 & GPHA-011 & HARC & SPS \\
19 & GPHA-015 & HARC & SPS \\
20 & P -313-010 & ICARDA & Australia \\
21 & P -313-045 & ICARDA & Australia \\
22 & P -313-086 & ICARDA & Australia \\
23 & P -313-082 & ICARDA & Australia \\
24 & P -313-042 & ICARDA & Australia \\
25 & P-313-071 & ICARDA & Australia \\
26 & PDFP-BEK & ICARDA & Australia \\
27 & G 227 63-2C & HARC & G22763-2c \\
28 & P -313-053 & ICARDA & Australia \\
29 & P -313-070 & ICARDA & Australia \\
30 & P -313-027 & ICARDA & Australia \\
31 & P -313-065 & ICARDA & Australia \\
32 & P -313-026 & ICARDA & Australia \\
33 & P -313-090 & ICARDA & Australia \\
34 & P -313-046 & ICARDA & Australia \\
\hline
\end{tabular}




\begin{tabular}{llll}
\hline No & Genotype & Source & Origin \\
\hline 35 & MILKEY & HARC & NEP634 X1801/Holeta \\
36 & & P-313-098 ICARDA Australia \\
37 & HASABE & HARC & JI No 116 \\
38 & HOLETA & HARC & Holeta local-90 \\
39 & WALMERA & HARC & FpExDz X 305PS2108-22-1 \\
40 & & p-313-059 & ICARDA Australia \\
41 & p-313-061 & ICARDA & Australia \\
42 & p-313-068 & ICARDA & Australia \\
43 & p-313-089 & ICARDA & Australia \\
44 & p-313-067 & ICARDA & Australia \\
45 & p-313-003 & ICARDA & Australia \\
46 & ADI & HARC & G22763-2C X 305PS210813-2 \\
47 & BURKITU & HARC & EH-92004-02 \\
48 & BILALO & KARC & \\
49 & BURSA & KARC & \\
\hline
\end{tabular}

Where, KARC=kulumsa Agricultural Research Center, HARC=Holeta Agricultural Research Center, ICARDA=International Center of Agricultural Research for Dry Areas,

SPS- Single plant selection from bulked gene pool

\subsection{Experimental Design and Treatments}

The experiment was laid out in a $7 \times 7$ simple lattice design. Each plot consisted of two rows of $4 \mathrm{~m}$ length with spacing of $20 \mathrm{~cm}$ between rows and $5 \mathrm{~cm}$ between plants. Each genotype was planted in a plot size of $1.6 \mathrm{~m}^{2}$. The space between plots within block was $1 \mathrm{~m}$ and between blocks was $1.5 \mathrm{~m}$. Each row was sown 80 seeds and each plots contained total of 160 seeds. Fertilizer (100 Kg/ha DAP) was applied during planting. Weeding and all other recommended agronomic practices were followed in both locations. For statistical analysis, yield from net plot area of $1.6 \mathrm{~m}^{2}$ was harvested and converted into $\mathrm{kg} \mathrm{ha}^{-1}$ base at $10 \%$ standard grain moisture content.

\subsection{Data Collection and Analysis}

Data on days to $50 \%$ flowering, days to $95 \%$ physiological maturity, 1000 seed weight $(\mathrm{g})$, grain yield $\left(\mathrm{kg} \mathrm{ha}^{-1}\right)$, ascochyta blight (1-9scale), and powdery mildew (1-9scale) were assessed on plot bases, while plant height $(\mathrm{cm})$, number of pods plant-1, and number of seeds pod-1 were recorded on five random samples of plants selected from each plot. Mean values of the five random samples of plants plot-1 were then used for the analysis of data collected on an individual plant basis.

Data for all traits were subjected to analysis of variance using General Linear Model (PROC GLM) of the SAS Procedure using version 9.0 of the software [25]. The significance of variance effects was considered at $\mathrm{P} \leq 0.05$, $\mathrm{P} \leq 0.01$, and $\mathrm{P} \leq 0.001$.

Homogeneity of error mean square between the two locations was tested by F-test [13] and combined analyses were performed for all parameters whose error mean squares were homogenous Mean comparison among genotype were carried out using Duncan Multiple range Test (DMRT) [8]. Genetic parameter such as phenotypic and genotypic variance, heritability, phenotypic and genotypic coefficient of variations, genetic advance and genetic advance as percentage of mean were calculated by adopting the following equations suggested by biometricians. The phenotypic and genotypic variances were estimated according to the method suggested by [29] as follows:

Genotypic Variance $\left(\sigma^{2} \mathrm{~g}\right)=(\mathrm{MSg}-\mathrm{MSe}) / \mathrm{r}$ (for individual location)

Environmental variance $\left(\sigma^{2} \mathrm{e}\right)=\mathrm{MSe}$ (error mean square)

Phenotypic variance $\left(\sigma^{2} p\right)=\sigma^{2} g+\left(\sigma^{2} e / r\right)$ (for individual location)

Genotypic Variance $\left(\sigma^{2} \mathrm{~g}\right)=(\mathrm{MSg}-\mathrm{MSg} * \mathrm{l}) / \mathrm{rl}$ (for combined location)

Genotypes X location Variance $\left(\sigma^{2} \mathrm{~g}^{*} \mathrm{l}\right)=\left(\mathrm{MSg}^{*} \mathrm{l}-\mathrm{MSe}\right) / \mathrm{r}$ (for combined over locations)

Phenotypic variance $\left(\sigma^{2} p\right)=\sigma^{2} g+\left(\sigma^{2} \mathrm{e} / \mathrm{rl}\right)+\left(\sigma^{2} \mathrm{~g} * \mathrm{l} / \mathrm{l}\right)$ (for combined over locations)

Where, $\mathrm{MSg}=$ mean square due to genotypes, $\mathrm{MSe}=$ error mean square, $\mathrm{r}=$ number of replication, $\mathrm{MSg}^{*} \mathrm{l}=$ mean square due to genotypes $\mathrm{X}$ location, $1=$ number of location Genotypic and phenotypic coefficients of variability were estimated according to the [5] by using the following formulae.

$$
\begin{aligned}
& \mathrm{PCV}=\frac{\sqrt{\sigma^{2} p}}{\bar{X}} \times 100 \\
& \mathrm{GCV}=\frac{\sqrt{\sigma^{2} g}}{\bar{X}} \times 100
\end{aligned}
$$

Where, PCV = Phenotypic Coefficient of variation, GCV = Genotypic Coefficient of variation

$\sigma^{2} p=$ Phenotypic variance, $\sigma^{2} g=$ Genotypic Variance, $x$ $=$ mean value of the trait

[7] classified the PCV and GCV estimates as follows:

Low, $<10 \%$, Moderate, 10-20\%, High, $>20 \%$

Broad sense heritability values for all parameters $\left(h^{2}(b)\right)$ were estimated based on the formula given by [10] as follows:

$$
h^{2}(b)=\frac{\sigma^{2} g}{\sigma^{2} p} \times 100
$$

According to [14] the heritability $\left(\mathrm{h}^{2}(\mathrm{~b})\right)$ was categorized as:

Low, 0-30\%, Medium, 31-60\%, High, $>60 \%$

Genetic advance (GA) was estimated as per formula given by [2].

$$
\mathrm{GA}=\mathrm{K} \times \sqrt{\sigma^{2} p} \times \mathrm{h}^{2}(\mathrm{~b})
$$

Where; $\mathrm{K}=$ Selection differential at 5 per cent selection intensity which accounts to a constant value $2.06, \sigma^{2} \mathrm{p}=$ Phenotypic variance, h2 (b) =Broad sense heritability

Genetic advance over mean (GAM) was calculated using the following formula and was expressed in percentage.

$$
\mathrm{GAM}=\frac{G A}{X} \times 100
$$

According to [14] the GAM can be placed in following categorizes.

Low, $<10 \%$, Moderate, $10-20 \%$, High, $>20 \%$ 


\section{Results and Discussion}

\subsection{Analysis of Variances (ANOVA)}

All traits showed homogenous error mean square and the combined/pooled / analysis of variance revealed highly significant $(P \leq 0.01)$ to significant $(P \leq 0.05)$ main effect differences for genotypes observed for the traits under study except for number of seeds pod ${ }^{-1}$ (Table 3 ). The significant differences obtained in the present experiment indicated the presence of considerable variation in the genetic materials studied. The finding in this study was in agreement with report of [32] where, highly significant to significant differences between twenty four field pea genotype for plant height, harvest index, biological yield, thousand seed weightand grain yield except seed per plant and pod per plant [22] indicated highly significant variations among forty six pea genotypes for all the characters studied viz., days to $50 \%$ flowering, grain filling period, days to $90 \%$ maturity, plant height, number of pods per plant, seeds per pod, seeds per plant, ascochyta blight, powdery mildew, thousand seed weight and grain yield ( $\mathrm{Kg} / \mathrm{ha})$.

[4] also observed highly significant differences for days to flower initiation, days to maturity, plant height, pod length, above ground biomass and 100 seed weight. Thus, it revealed that the presence of adequate variability which can be exploited through selection in breeding of crop for improvement of yield of field pea.

Test locations exerted highly significant to significanteffects on stand count, days to flowering, and days to maturity, plant height, seeds per pod, thousand seed weight, ascochyta blight and powdery mildew indicating the phenotypic expression of these traits was different at both locations. Non- significant location effects were observed for number of pods per plant and grain yield $\left(\mathrm{kgh}^{-1}\right)$ (Table 3$)$.

Similar result were also reported by [32] where, biological yield, seed per plant, hundred seed weight, plant height \&Harvest index exhibited highly significant locations effect among twenty four field pea genotypes evaluated.

The interaction effects of locations and genotypes were exerted highly significant to significant effects for all traits studied except days to $50 \%$ flowering, days to $95 \%$ maturity and plant height (Table 3). Significant to highly significant of genotype $(G) x$ location (L) interaction observed in this study indicated the differential response of genotypes for those traits at each location. [30] reported highly significant to significant location effect on grain yield, powdery mildew and number of pods per plant and non-significant on plant height.

\subsection{Range and Mean Performance of Field Pea Genotypes Combined over the Two Locations}

The range and mean for the traits studied are presented in Table 4. Days to flowering was varied from 74 to 83 day with a mean of 78 . Days to maturity ranged from 139 to 147 with a mean of 143. Traits like plant height, number of pods per plant, thousand seed weight and seed yield among genotypes showed wider variation. The plant height varied from 85 to $141 \mathrm{~cm}$ with a mean of $110.8 \mathrm{~cm}$. Most of semi leafless type genotypes were shorter, and erect and tolerance to lodging while normal leaf type genotypes were longer, prostrate and susceptible to lodging. The number of pods per plant ranged from 7 to 11 with a mean of 8 . The thousand seed weight exhibited a wider range from 153 to $259 \mathrm{gm}$ with a mean of $188.69 \mathrm{gm}$. The seed yield ranged from 1955 to $5997 \mathrm{~kg} \mathrm{ha}^{-1}$ with a mean of $3803 \mathrm{~kg}$ across the two locations (Tables 4 and 5). Two genotypes PDFPT-BEK and P-313-053 were relatively high yielder over the two locations. In general, the range and mean of most traits in this study showed the existence of sufficient variability among the tested genotypes and good potential were found for field pea improvement.

Table 3. Mean squares from a combined analysis of variance for ten traits of 49 field pea genotypes tested across two locations.

\begin{tabular}{|c|c|c|c|c|c|c|c|}
\hline \multirow[b]{2}{*}{ Traits } & \multicolumn{7}{|l|}{ Mean Square } \\
\hline & $\operatorname{LOC}(\mathrm{df}=1)$ & $\begin{array}{l}\text { REP/LOC } \\
(\mathrm{df}=2)\end{array}$ & $\begin{array}{l}\text { BLOCK/REP*LO } \\
\text { C }(d f=24)\end{array}$ & $\begin{array}{l}\text { GENOTYPE } \\
(\mathrm{df}=48)\end{array}$ & $\begin{array}{l}\text { LOC*GENOTYPE } \\
(\mathrm{df}=48)\end{array}$ & $\begin{array}{l}\text { Error } \\
(d f=72)\end{array}$ & $\begin{array}{l}\text { CV } \\
(\%)\end{array}$ \\
\hline Stand count & $2809^{* * *}$ & 827.59 & 101.28 & $148.53^{* * *}$ & $55.86^{*}$ & 30.79 & 6.62 \\
\hline Days to $50 \%$ flowering & $43.2^{* * *}$ & 0.27 & 1.59 & $15.13^{* * *}$ & $1.40^{\mathrm{ns}}$ & 1.21 & 1.42 \\
\hline Days to $95 \%$ Maturity & $16512.3^{* * *}$ & 26.58 & 78.41 & $12.16^{* * *}$ & $2.93^{\mathrm{ns}}$ & 2.34 & 1.07 \\
\hline Plant height $(\mathrm{cm})$ & $53724.6^{* * *}$ & 1849.23 & 156.56 & $666.32^{* * *}$ & $144.67^{\mathrm{ns}}$ & 100.87 & 9.06 \\
\hline Number of pods plant- 1 & $1.8^{\mathrm{ns}}$ & 15.94 & 1.99 & $2.72^{* * *}$ & $1.70^{*}$ & 1.04 & 12.23 \\
\hline 1000 seed weight $(\mathrm{g})$ & $130011.8^{* * *}$ & 186.94 & 82.62 & $1608.34^{* * *}$ & $288.44^{* * *}$ & 75.71 & 4.61 \\
\hline Grain yield $\left(\mathrm{kg} \mathrm{ha}^{-1}\right)$ & $1294980.8^{\mathrm{ns}}$ & 7249826.90 & 511565.80 & $4592338.60^{* * *}$ & $1690687.40^{* * *}$ & 402246.60 & 16.68 \\
\hline Ascochyta blight (1-9) & $246.9^{* * *}$ & 0.41 & 0.41 & $0.79^{* *}$ & $0.60^{*}$ & 0.37 & 14.13 \\
\hline Powdery mildew (1-9) & $490.3^{* * *}$ & 0.53 & 0.45 & $0.56^{* * *}$ & $0.42 *$ & 0.24 & 18 \\
\hline
\end{tabular}

$*, * *, * *$ and $\mathrm{ns}$ were significant at $P \leq 0.05$, highly significant at $P \leq 0.01$, very highly significant at $P \leq 0.001$ and non-significant at $\mathrm{p}>0.05$ respectively. CV $=$ coefficient of variation, $\mathrm{df}=$ degree of freedom.

\subsection{Phenotypic and Genotypic Variations}

Variance components, phenotypic coefficient of variation (PCV) and genotypic coefficient of variation (GCV) for the characters studied combined over the two locations are presented in Table 4.

The estimates of phenotypic and genotypic variances were the highest for grain yield, 1000 grains weight and plant height and the lowest for powderymildew, ascocayta blight and number of pods per plant.

The genotypic coefficient of variation (GCV) ranged from 
(1.07\%) for days to maturity to $(22.40 \%)$ for grain yield, while phenotypic coefficient of variation (PCV) also ranged from $(1.22 \%)$ for days to maturity to $(28.18 \%)$ for grain yield.

In general, phenotypic coefficient of variation (PCV) was higher than genotypic coefficient of variation (GCV) although the differences were small. The small differences indicated that the environmental effect was small for the expression of most characters. This finding confirmed the previous report by [4]. However, significantly higher PCV than GCV values observed for number of pods per plant, stand count, powdery mildew and ascocayta blight incidence suggests the significant contribution of environment and genotype by environment effect than genetic factors in the expression of these traits. In these traits, selection based on the phenotype performance may not be appropriate. Because the magnitude of genetic variation is better assessed from GCV than PCV, breeders commonly focus on traits with high GCV estimates reported by [15].

[26 and 30] suggested that larger difference between GCV and $\mathrm{PCV}$ is due to larger influence of environment and genotype by environment effect on that trait.

According to [7] genotypic and phenotypic coefficient of variations can be categorized as low $(<10 \%)$, medium (10$20 \%)$ and high $(>20 \%)$.
In the preset study, both GCV and PCV were low for days to flowering and days to maturity. The low value of this variation also indicates that the selection is not effective for this character because of the narrow genetic variability even though it showed less influence of environment effect to the expression of these traits

Powdery mildew, pods plant ${ }^{-1}$, Stand count, seeds pod ${ }^{-1}$, ascochyta blight, and showed low or relatively moderate GCV values. The low value of this variation indicates that the selection is not effective for this character because of the narrow genetic variability and the significant contribution of environment and genotype by environment effect to the expression of these traits.

Moderate or relatively high PCV values were noted for powdery mildew $(13.84 \%)$, plant height $(11.65 \%)$, seed weight $(10.63 \%)$, ascocayta blight $(10.34 \%)$ and number of pods plant-1 $(9.90 \%)$.

High PCV and GCV values (>20\%) observed for grain yield $(28.18 \%, 22.40 \%)$ and moderate PCV and GCV values $(10-20 \%)$ For 1000 seed weight $(10.63 \%, 9.63 \%)$ and plant height $(11.65 \%, \quad 10.30 \%)$ respectively, indicating the existence of wide genetic variation for these traits among the genotypes, and there could be much potential for improving these traits through hybridization and/ or direct selection.

Table 4. Genotypic variance $\left(\sigma^{2} g\right)$, environmental variance $\left(\sigma^{2} e\right)$, GxL variance $\left(\sigma 2 g^{*} l\right)$, phenotypic variance $\left(\sigma^{2}\right.$ p); genotypic $(G C V)$ and phenotypic $(P C V)$ coefficient of variation, heritability in the broad sense (Hb2), and genetic advance and genetic advance in percent of the mean (GAM) of ten traits of 49 field pea genotypes from combined ANOVA over two locations; bekoji and kofele.

\begin{tabular}{|c|c|c|c|c|c|c|}
\hline Traits & Range & Mean & $\sigma^{2} g$ & $\sigma^{2} g * I$ & $\sigma^{2} \mathrm{e}$ & $\sigma^{2} p$ \\
\hline Stand (\%) & $56-94$ & 83.77 & 23.17 & 12.53 & 30.79 & 37.13 \\
\hline Days to $50 \%$ flowering & $74-83$ & 77.71 & 3.43 & 0.10 & 1.21 & 3.78 \\
\hline Days to $95 \%$ Maturity & $139-147$ & 142.62 & 2.31 & 0.29 & 2.34 & 3.04 \\
\hline Plant height $(\mathrm{cm})$ & $85-141$ & 110.83 & 130.41 & 21.90 & 100.87 & 166.58 \\
\hline Number of pods plant ${ }^{-1}$ & $7-11$ & 8.33 & 0.26 & 0.33 & 1.04 & 0.68 \\
\hline Number of seeds pod ${ }^{-1}$ & 3.9-5.9 & 5.00 & 0.07 & 0.06 & 0.37 & 0.20 \\
\hline 1000 seed weight $(\mathrm{g})$ & $153-259$ & 188.69 & 329.98 & 106.36 & 75.71 & 402.09 \\
\hline Ascochyta blight (1-9) & $2.9-5$ & 4.29 & 0.05 & 0.12 & 0.37 & 0.20 \\
\hline Powdery mildew (1-9) & $1.8-3.6$ & 2.70 & 0.03 & 0.09 & 0.24 & 0.14 \\
\hline
\end{tabular}

Table 4. Continued.

\begin{tabular}{|c|c|c|c|c|c|c|}
\hline Traits & PCV\% & GCV\% & ECV\% & H2 & GA & GAM\% \\
\hline Stand (\%) & 7.27 & 5.75 & 6.62 & 62.39 & 7.84 & 9.36 \\
\hline Days to $50 \%$ flowering & 2.50 & 2.38 & 1.42 & 90.73 & 3.64 & 4.68 \\
\hline Days to $95 \%$ Maturity & 1.22 & 1.07 & 1.07 & 75.93 & 2.73 & 1.92 \\
\hline Plant height $(\mathrm{cm})$ & 11.65 & 10.30 & 9.06 & 78.29 & 20.85 & 18.81 \\
\hline Number of pods plant ${ }^{-1}$ & 9.90 & 6.07 & 12.23 & 37.59 & 0.64 & 7.68 \\
\hline Number of seeds pod ${ }^{-1}$ & 8.86 & 5.40 & 12.09 & 37.13 & 0.34 & 6.79 \\
\hline 1000 seed weight $(\mathrm{g})$ & 10.63 & 9.63 & 4.61 & 82.07 & 33.95 & 17.99 \\
\hline Ascochyta blight (1-9) & 10.34 & 5.03 & 14.13 & 23.66 & 0.22 & 5.05 \\
\hline Powdery mildew (1-9) & 13.84 & 6.83 & 18.00 & 24.36 & 0.19 & 6.96 \\
\hline
\end{tabular}

PCV and GCV with higher value specified that the genotypes show evidence of much variation among themselves with respect to these characters. This indicated that selection may be effective based on these characters and their phenotypic expression would be a good indication of genotypic potential. The estimates are consistent with the findings of [30] where, high level of genetic variation was observed for grain yield and relatively high variation for seed size and [4] reported moderate PCV and GCV for 1000 seed weight.

Insignificant differences between PCV and GCV values observed for days to flowering, days to maturity, plant height, 1000 seed weight, and grain yield indicating that the observed variations were owing to genetic factors; hence, the environmental effect played a little role in the expression of these traits. Similarly, small differences between PCV and 
GCV values in most of the traits studied were reported by [30 and 28] except grain yield.

\subsection{Estimates of Heritability (Hb2) in Broad Sense}

Estimates of broad sense heritability $(\mathrm{Hb} 2)$ are presented in Table 4.

In the present work, heritability estimate for 10 characters studied indicated that, $\mathrm{Hb} 2$ values varied from low to high depending on the traits under study. It was ranged from $23.66 \%$ for ascocayta blight to $90.73 \%$ for days to flowering (Table 4).

According to [14] the heritability $\left(\mathrm{h}^{2}(\mathrm{~b})\right)$ was categorized as low, $0-30 \%$, medium, 31-60\%, high, $>60 \%$.

In this study, High estimates of $\mathrm{Hb} 2$ observed for days to flowering $(90.73 \%)$, seed size $(82.07 \%)$, plant height (78.29\%), days to maturity $(75.93 \%)$, grain yield $(63.18 \%)$ and standcount $(62.39 \%)$. Low $\mathrm{Hb} 2$ estimate was noted for ascocayta blight $(23.66 \%)$ and powdery mildew $(24.36 \%)$. Whereas moderate $\mathrm{Hb} 2$ estimates noted for number of pods per plant and number of seeds pod $^{-1}$. Such moderate value indicted the limit scope for crop improvement of these characters. This result was in agreement with the report of [4] who have shown in field pea have high broad sense heritability in day to flowering, day to maturity and 100 seed weight. [30] also reported high heritability in days to flowering, maturity, 1000 seed weight and grain yield in field pea genotypes.

Most the characters studied show high heritability estimates indicate less influence of the environment, and so there is a good scope for the improvement of these traits through selection. This result was similar with the finding of [4 and 30].

\subsection{Estimates of Expected Genetic Advance (GA)}

The estimated genetic advance and expected genetic advance as percent of the mean for the characters are presented in Table 4.

The genetic gain expected from selection of the superior $5 \%$ of the genotypes varied from a low $(1.92 \%)$ for days to maturity to high $(36.73 \%$ ) for grain yield (Table 4$)$

According to Johnson et al. (1955) the GAM can be placed aslow, $<10 \%$, moderate, $10-20 \%$, high, $>20 \%$.

Moderate or relatively high value of GAM in plant height and seed size was observed. Comparatively, Value of genetic advance as a percent of mean for stand, number of pods per plant, number of seeds per pod, ascochyta blight and powdery mildew incidence were relatively moderate. Low value of GAM for days to $50 \%$ flowering and days to $95 \%$ maturity was recorded.

Since high heritability does not always indicate a high genetic gain, heritability with genetic advance considered together should be used in predicting the ultimate effect of selecting superior varieties [1]. The effectiveness of selection depends upon genetic advance of the character selected along with heritability [17].

The GCV, along with heritability estimates, provides reliable estimates of the amount of GA to be expected through phenotypic selection.

High GCV, along with high heritability and high GAM, provides better information than single parameters alone [3].

In the current study, values for $\mathrm{Hb} 2$ and GAM ranged from $23.66 \%$ to $90.73 \%$, and 1.92 to $36.73 \%$, respectively (Table 4 ). These values are lower in $\mathrm{Hb} 2$ and higher in GAM compared to the values reported by [30]. This is because both variation in additive and non-additive genetic factors and the environmental variance are population specific [21], heritability in one population does not necessarily predict the heritability of the same traits in another population. On the other hand, this large difference in $\mathrm{Hb} 2$ values of similar traits of field pea genotypes could be explained by the difference in data used from two locations in the current study compared to four location used in other study [19]. Differences in $\mathrm{Hb} 2$ of traits in this study may have resulted either due to some traits may be inherently less variable than the others, or there are differences in the magnitude of environmental influence on phenotypic performances of the genotypes.

Higher heritability (H2) coupled with high GAM observed for grain yield per ha and higher heritability (H2) coupled with moderate or relatively high value of GAM in plant height and seed size; indicating that the phenotype of an individual in the current population is a good indicator of the genotypes or it mean that most of the variation in this traits observed in the present population is caused by variation in genotypes. This suggests the predominance of additive gene action in the expression of this traits [9], making it to easily transferred from parent to offspring. Hence; based on this traits selection will be effective. This is partially close agree with the findings of [30], where high heritability estimates in field pea were associated with high genetic advance as a percent of mean for seed size, high heritability with moderate GAM for grain yield and low heritability with low GAM for plant height. A high $\mathrm{Hb} 2$ value for plant height was reported by [16].

High estimates of $\mathrm{Hb} 2$ and relatively moderate estimates of GAM were observed for stand count. In such cases, the coexistence of additive and non- additive gene action would be responsible for the expression of these trait [23 and 9]. [19] reported moderate GAM but low $\mathrm{Hb} 2$ for stand count.

Days to flowering and days to maturity possessed high $\mathrm{Hb} 2$ with low GAM, and this is in line with the findings of [26 and 30], suggesting the predominance of non-additive gene action. On the other hand, the high $\mathrm{Hb} 2$ of these characters could be as a result of the favorable environmental condition rather than genotypic effect, thus simple selection procedure in early segregating generations will not be effective for screening of this traits.

The low $\mathrm{Hb} 2$ values as coupled with low GAM for ascocayta blight, powdery mildew, number of pods plant-1 and number of seeds pod-1 indicated that only a small proportion is caused by variation in genotypes. The reason for the low heritability is a result of some variances constituting the environmental variance. This low estimate of genetic advance as a percent mean arises from low estimate of phenotypic variance and heritability. In this case, one 
could expect slow progress of improvement in these traits through direct selection due to a quantitative mode of inheritance. Similarly, low $\mathrm{Hb} 2$ and GAM values for powdery mildew, number of pods plant-1, and number of seeds pod-1 were reported in [19and 30] but contrast to this result, high $\mathrm{Hb} 2$ values for number of pods plant-1 and number of seeds pod-1 was reported by [4].

Table 5. Mean grain yield (Kg ha $\left.{ }^{-1}\right)$ for 49 tested Field pea genotypes in Bekoje, Kofele and combined over locations.

\begin{tabular}{|c|c|c|c|c|}
\hline No. & Genotype & Bekoje & Kofele & Mean \\
\hline 1 & GPHA-05 & 3854 & 1726 & $2790^{\mathrm{jklmnop}}$ \\
\hline 2 & GPHA-013 & 2941 & 2564 & $27531^{\mathrm{mnop}}$ \\
\hline 3 & GPHA-03 & 1820 & 2508 & $2164^{\mathrm{op}}$ \\
\hline 4 & GPHA-019 & 2862 & 4904 & $3883^{\text {hijkl }}$ \\
\hline 5 & GPHA-02 & 4827 & 3441 & $4134^{\text {fghij }}$ \\
\hline 6 & GPHA-010 & 4305 & 3171 & $3738^{\text {hijkl }}$ \\
\hline 7 & GPHA-07 & 3713 & 1632 & $26721^{\text {mnop }}$ \\
\hline 8 & GPHA-08 & 3858 & 2926 & $3392^{\mathrm{jklmnop}}$ \\
\hline 9 & GPHA-06 & 4032 & 4669 & $4351^{\text {fghi }}$ \\
\hline 10 & GPHA-012 & 2792 & 3180 & $2986^{\mathrm{jklmnop}}$ \\
\hline 11 & GPHA-04 & 4593 & 2707 & $3650^{\text {hijklmn }}$ \\
\hline 12 & GPHA-016 & 3050 & 1618 & $2334^{\text {nop }}$ \\
\hline 13 & GPHA-09 & 3735 & 3301 & $3518^{\text {hijkl }}$ \\
\hline 14 & GPHA-01 & 3862 & 2347 & $3105^{\mathrm{klmnop}}$ \\
\hline 15 & GPHA-018 & 4192 & 1801 & $2997^{\mathrm{jklmnop}}$ \\
\hline 16 & GPHA-017 & 3104 & 2642 & $2873^{\mathrm{Imnop}}$ \\
\hline 17 & GPHA-014 & 3578 & 1678 & $2628^{\mathrm{lmnop}}$ \\
\hline 18 & GPHA-011 & 2017 & 1894 & $1955^{\mathrm{p}}$ \\
\hline 19 & GPHA-015 & 4731 & 5050 & $4891^{\mathrm{efg}}$ \\
\hline 20 & $P-313-010$ & 3078 & 5582 & $4330^{\text {ghijk }}$ \\
\hline 21 & $P-313-045$ & 2676 & 3754 & $3215^{\mathrm{jklmno}}$ \\
\hline 22 & P -313-086 & 3422 & 3973 & $3697^{\text {hijkl }}$ \\
\hline 23 & P -313-082 & 3702 & 5582 & $4642^{\mathrm{fgh}}$ \\
\hline 24 & P -313-042 & 3752 & 3408 & $3580^{\mathrm{ijk} \mathrm{kmn}}$ \\
\hline 25 & P -313-071 & 3804 & 2510 & $3157^{\mathrm{klmnop}}$ \\
\hline 26 & PDFPT-BEK & 6081 & 5913 & $5997^{\mathrm{a}}$ \\
\hline 27 & G $22763-2 C$ & 4062 & 2170 & $3116^{\text {hijklmn }}$ \\
\hline 28 & $\mathrm{P}-313-053$ & 5474 & 6100 & $5787^{\text {cde }}$ \\
\hline 29 & P -313-070 & 3525 & 3807 & $3666^{\text {hijklm }}$ \\
\hline 30 & $\mathrm{P}-313-027$ & 1855 & 3671 & $2763^{\mathrm{lmnop}}$ \\
\hline 31 & $P-313-065$ & 2544 & 3950 & $3247^{\mathrm{jklmnop}}$ \\
\hline 32 & P -313-026 & 3928 & 4414 & $4171^{\text {fghi }}$ \\
\hline 33 & P -313-090 & 3489 & 4425 & $3957^{\text {hijkl }}$ \\
\hline 34 & $P-313-046$ & 4329 & 4454 & $4392^{\text {fghi }}$ \\
\hline 35 & MILKEY & 4546 & 5724 & $5135^{\mathrm{ef}}$ \\
\hline 36 & P-313-098 & 2080 & 2914 & $2497^{\text {mnop }}$ \\
\hline 37 & HASABE & 2721 & 3223 & $2972^{\mathrm{jklmnop}}$ \\
\hline 38 & HOLETA & 3550 & 3792 & $3671^{\text {fghij }}$ \\
\hline 39 & WALMERA & 4683 & 3621 & $4152^{\mathrm{fgh}}$ \\
\hline 40 & p-313-059 & 2800 & 2738 & $2769^{\mathrm{klmnop}}$ \\
\hline 41 & p-313-061 & 4175 & 3513 & $3844^{\mathrm{hijkl}}$ \\
\hline 42 & p-313-068 & 3503 & 3740 & $3621^{\text {hijklmn }}$ \\
\hline 43 & p-313-089 & 2477 & 3118 & $2797^{\mathrm{mnop}}$ \\
\hline 44 & $p-313-067$ & 3040 & 5850 & $4445^{\mathrm{ef}}$ \\
\hline 45 & $\mathrm{p}-313-003$ & 3869 & 2882 & $3375^{\mathrm{hijklm}}$ \\
\hline 46 & $\mathrm{ADI}$ & 5631 & 5886 & $5758^{\text {bcd }}$ \\
\hline 47 & BURKITU & 4513 & 5734 & $5123^{\operatorname{def}}$ \\
\hline 48 & BILALO & 5141 & 6627 & $5884^{\mathrm{ab}}$ \\
\hline \multirow[t]{4}{*}{49} & BURSA & 6043 & 5397 & $5720^{\mathrm{abc}}$ \\
\hline & Mean & 3038 & 3884 & 3803 \\
\hline & CV (\%) & 16.75 & 16.6 & 16.6 \\
\hline & R-square (\%) & 89 & 94 & 93 \\
\hline
\end{tabular}

\section{Conclusion}

The combined/pooled / analysis of variance revealed highly significant $(P \leq 0.01)$ to significant $(P \leq 0.05)$ differences among genotypes observed for all traits under study except for number of seeds pod ${ }^{-1}$. The present studies showed that low to high genotypic and phenotypic coefficient of variation observed for most of the traits. The PCV values were relatively greater than GCV in magnitude for all characters under study. However, significantly higher PCV than GCV values observed for number of pods per plant, stand count, powdery mildew and ascocayta blight incidence suggests the significant contribution of environment and genotype by environment effect than genetic factors in the expression of these traits. Insignificant differences between PCV and GCV values observed for days to flowering, days to maturity, plant height, 1000 seed weight and grain yield indicating that the observed variations were owing to genetic factors; hence, the environmental effect played a little role in the expression of these traits. Broad sense heritability ranged from $23.66 \%$ for ascochyta blight to $90.73 \%$ for days to flowering. The genetic advance as percentage of means varied from $1.92 \%$ for days to maturity to $36.73 \%$ for grain yield.

Higher heritability (H2) coupled with high GAM observed for grain yield per ha and higher heritability (H2) coupled with moderate or relatively high value of GAM in plant height and seed size. To confirm with the present finding, it must be further studied in a number of years and locations with more number of genotypes.

\section{Conflict of Interests}

The authors have not declared any conflict of interests.

\section{References}

[1] Ali A, Khan S, Asad MA (2002). Drought tolerance in wheat: Genetic variation and heritability for growth and ion relations. Asian Journal of Plant Science, 1: 420-422.

[2] Allard RW (1960). Principles of Plant Breeding. John Wiley and Sons Inc. New York.

[3] Baye B, Ravishankar R, Singh H (2005). Variability and association of tuber yield and related traits in potato (Solanum tuberosum L.). Ethiopian Journal of Agricultural Science, 18: $103-121$.

[4] Benti O and Yohannis P (2017). Genetic variability and association among agronomic characters in selected field pea (Pisumsativum L.) genotypes at Bale Zone, Sinana Research Center, Oromia. International Journal of Genetics and Genomics, 5 (6): 63-75.

[5] Burton GW, Devance EH (1953). Estimation of heritability in tall Festuca (Festucaarudindces) from replicated colonial material. Agronomy Journal, 45: 78-481.

[6] CSA (Central Statistical Authority). 2018. Agricultural sample survey 2009/10. Report on area and production of major crops private peasant holdings, Meher Season. Addis Ababa. Statistical Bulletin no. 586. Volume 1. 
[7] Deshmukh SN, Basu MS, Reddy PS (1986). Genetic variability, character association and path coefficient analysis of quantitative traits in Virginia bunch varieties of groundnut. Indian Journal of Agricultural Sciences, 56: 515-518.

[8] Duncan BD (1955). Multiple Range Test and Multiple F. test. Biometrics, 11: 1-42.

[9] Elangovan M, Kiran Babu P, Seetharama N (2014). Genetic diversity and heritability characters associated in sweet sorghum [Sorghumbicolor (L.) Moench]. Journal of Sugar Technology, 16 (2): 200-210.

[10] Falconer DS, Mackay FC (1996). Introduction to Quantitative Genetics. Longman, New York.

[11] FAOSTAT (2017). Food and Agriculture Organization of the United Nations. Available online at http://www:fao.org/faostat/en/\#data/QC/visualize.

[12] Gemechu K, Mussa J, Tezera W, Getnet D (2005). Extent and pattern of genetic diversity of morpho-agronomic traits in Ethiopian highland pulse landraces. 1 in Field pea (Pisumsativum L.). Genetic Resource and Crop Evolution, 52: 539-549.

[13] Hartley HO (1950). The maximum F-ratio as a short-cut test for heterogeneity of variance. Biometrika, 37 (3/4): 308, 312.

[14] Johnson HW, Robinson HF. Comstock RE (1955). Genotypic and phenotypic correlations in soybean and other implications in selection. Agronomy Journal, 47: 477-483.

[15] Kebebew A, Gina C, Dejene G, Rizqah K, Solomon CH (2015). Genetic diversity in tef [Eragrostis tef (Zucc.) Trotter]. Frontiers of Plant Science, 6 (177): 1-13

[16] Kumar D, Malik S, Singh SK, Kumar M (2013). Genetic variability, heritability and genetic advance for seed yield and yield components in garden pea (Pisum sativum L.). Vegetos, 26 (1): 182-184.

[17] Manju PR, Sreelathakumary I (2002). Genetic variability, heritability and genetic advance in hot chilli (Capsicum chinense JACQ.). Journal of Tropical Agriculture, 40: 4-6.

[18] Messiaen CM, Seif AA, Jarso M, Keneni GA (2006). Pisum sativum L. internet record from PROTA4U. In. Brink M, Belay G (Eds.), PROTA: Plant Resources of Tropical Africa, Wageningen, Netherlands.

[19] Million F (2012). Variablity, Heriatablity and Associattion of Some Morpho-Agronomic Traits in Field Pea (Pisium Sativum L.) Genotypes. Pakistan Journal of Bilogical Science, 15 (80); 358-366

[20] Mussa J, Tezera W, Gemechu K (2006). Review of field pea (Pisum sativum L.) genetics and breeding research in Ethiopia: A review. In. Kemal A, Gemechu K, Seid A, Malhotra R, Beniwal S (Eds.), Food and Forage Legumes of Ethiopia: Progress and Prospects. Addis Ababa, Ethiopia, pp. 67-79.
[21] Peter MV, William GH, Naomi RW (2008). Heritability in the genomics era- concepts and misconceptions. Nature Review Genetics, 9: 255-266.

[22] Rafiul A, Firoz M, Mir AR (2017). Genetic diversity, correlation and path analysis for yield and yield components of pea (Pisumsativum L.). World Journal of Agricultural Sciences, 13 (1): 11-16.

[23] Ranjan S, Kumar M, Pandey SS (2006). Genetic variability in pea (Pisumsativum L.). Legume Research, 29 (4): 311-312.

[24] Sahile S, Ahmed S, Fininsa C, Abang M and Sakhuja PK (2008). Survey of chocolate spot (Botrytis fabae) disease of faba bean (Vicia faba L.) and assessment of factors influencing disease epidemics in northern Ethiopia. Crop Protection, 27: 1457-1463.

[25] SAS (Statistical Analysis System). 2002. System Analysis Software version 9.0. SAS Institute Inc., Cary, North Carolina, USA.

[26] Saxesena RR, Vidyakar V, Sishwakarma MK, Yadav PS, Meena ML, et al. (2014). Genetic variability and heritability analysis for some quantitative traits in field pea (Pisum sativum L.). Supplement on Genetics and Plant Breeding, 9 (2): 895-898.

[27] Singh BD (2001). Plant breeding: Principles and Methods. Kalyani Publishers, New Delhi.

[28] Singh BK, Deka BC, Ramakrishna Y (2014). Genetic variability, heritability and interrelationships in pole-type French bean (Phaseolus vulgaris L.). Proceedings of the National Academy of Science, India, Section B Biological Science, 84 (3): 587-592.

[29] Singh RK, Chaudhary BD (1985). Biometrical Methods in Quantitative Genetic Analysis, Kalyani Publishers, New Delhi, PP. 318.

[30] Tamene TT (2017). Genetic Variation, Heritability, And Advances From Selection In Elite Breeding Materials Of Field Pea (Pisum Sativum L.). Agrecultural Research and $\begin{array}{lcccc}\text { Technology, } & 8 & \text { (4): } & 555740 . & \text { DOI: }\end{array}$ 10.19080/ARTOAJ.2017.08.555744.

[31] Teshome E, and Tegegn A (2017). Comparative Study of Powdery Mildew (Erysiphe polygoni) Disease Severity and Its Effect on Yield and Yield Components of Field Pea (Pisum sativum L.) in the Southeastern Oromia, Ethiopia. Journal of Plant Pathol ogy and Microbiology, 8: 410. doi: 10.4172/2157-7471.1000410

[32] Yasin G, Mathewos A (2014). Evaluation of field pea (Pisum sativum L.) genotypes performance for yield and yield components at five growing environments of southern Ethiopia. Current Research in Agricultural Sciences, 1 (3): 6576. 